\title{
目
}

Arch. Min. Sci. 62 (2017), 3, 531-543

Electronic version (in color) of this paper is available: http://mining.archives.pl

DOI 10.1515/amsc-2017-0039

ERYK REMIORZ*\#

\section{DETERMINATION OF CRITICAL ROCK MASS IN A BUCKET OF A DINTING LOADER}

\author{
WYZNACZENIE MASY KRYTYCZNEJ UROBKU W CZERPAKU LADOWARKI \\ DO POBIERKI SPĄGU
}

\begin{abstract}
The extraction of hard coal deposits lying in increasing depth causes significant problems with maintenance of roadways (maingates, tailgates, etc.). The reduction of the cross section of such excavations, caused by the floor upheaval, leads to the occurrence of many problems with transport and ventilation. Dinting loaders are employed to restore the original size of roadways tightened due to the activity of adverse stresses occurring in the rock mass. These are tracked machines, usually with small width of about $1 \mathrm{~m}$. They often work in roadways with high longitudinal and lateral inclination, as a result of which they are especially susceptible to overturning.

The article presents a mathematical model allowing to determine the critical mass of broken rock in a bucket. The model also allows to determine spatial coordinates of a dinting loader's centre of gravity depending on temporary position of movable elements of the loader such as a turntable, boom, coupler and bucket, and depending on the level of loading the bucket with broken rock. It also enables to determine critical angles of the roadways' longitudinal and lateral inclination. The outcomes of computer studies of variations in the position of the loader's centre of gravity depending on deflection angles of moving elements of the loader and the mass of broken rock in the bucket are also presented. Variability ranges of spatial coordinates of the centre of gravity of the loader are also established and examples are given for values of the critical mass of broken rock in the bucket.
\end{abstract}

Keywords: dinting loader, centre of gravity, critical mass, broken rock

Ladowarki do pobierki spagu są maszynami wykorzystywanymi w wyrobiskach chodnikowych do mechanizacji prac związanych z pobierką spagu i ładowaniem urobku. Wykonywanie tych czynności jest zwykle trudne w realizacji ze względu na istniejące wyposażenie wyrobiska chodnikowego i konieczność utrzymania regularnego transportu szynowego lub taśmowego. Ze względu na zmniejszone przekroje wyrobisk chodnikowych z wypiętrzonym spagiem do pobierki spagu stosowane są ładowarki o długości kilku metrów i niewielkiej szerokości wynoszącej zwykle około $1 \mathrm{~m}$. Są one wyposażone w czerpaki skrzyniowe o pojemnościach wynoszących około $0,3 \div 0,4 \mathrm{~m}^{3}$.

* SILESIAN UNIVERSITY OF TECHNOLOGy, FACULTy OF MINING AND GEOLOGY, INSTITUTE OF MINING MECHANISATION, 2 AKADEMICKA STR., 44-100 GLIWICE, POLAND

\# Corresponding author: eryk.remiorz@polsl.pl 
Niekorzystny stosunek szerokości ładowarki do jej długości oraz znaczne wartości kątów wychylania wysięgnika i czerpaka, a także praca w wyrobiskach o dużym nachyleniu podłużnym i poprzecznym powodują, że maszyny te narażone są w szczególny sposób na wywrócenie. Bardzo ważnym czynnikiem wpływającym na możliwość wywrócenia się ładowarki do pobierki spągu jest obciążenie czerpaka urobkiem. Może się ono zmieniać się w bardzo szerokim przedziale. Zbyt duże obciążenie czerpaka urobkiem może spowodować wywrócenie się ładowarki pracującej nawet w zakresie dopuszczalnych przez producenta kątów nachylenia podłużnego i poprzecznego wyrobiska. Dlatego znajomość wartości masy krytycznej urobku wypełniającego czerpak jest bardzo istotna w aspekcie bezpieczeństwa pracowników obsługi ładowarki do pobierki spagu.

W artykule przedstawiono model matematyczny (wzory $1 \div 6$ ) służący do wyznaczenia masy krytycznej urobku w czerpaku dla danego nachylenia podłużnego i poprzecznego wyrobiska chodnikowego z uwzględnieniem możliwości wychylania się obrotnicy, wysięgnika, wahacza czerpaka i czerpaka. Model ten umożliwia również obliczenie współrzędnych przestrzennych środka ciężkości ładowarki do pobierki spagu w zależności od chwilowego wychylenia obrotnicy, wysięgnika, wahacza czerpaka i czerpaka oraz masy urobku w czerpaku. Ponadto pozwala on na wyznaczenie granicznych kątów nachylenia podłużnego i poprzecznego wyrobiska chodnikowego dla których ładowarka znajduje się w stanie równowagi chwiejnej.

Znajomość zmian położenia środka ciężkości ładowarki do pobierki spagu na skutek wychylania obrotnicy, wysięgnika, wahacza czerpaka i czerpaka (który może być obciążony urobkiem) pozwala na ocenę zachowania się maszyny w wyrobisku chodnikowym. Na rysunku 3 przedstawiono obliczone komputerowo chmury punktów odzwierciedlające możliwe położenia środka ciężkości badanej ładowarki do pobierki spagu dla całego zakresu wychyleń obrotnicy, wysięgnika, wahacza czerpaka i czerpaka w przyjętym globalnym układzie współrzędnych XYZ (Rys. 2) dla następujących wartości masy urobku w czerpaku: $m_{B r}=0 \mathrm{~kg}, m_{B r}=400 \mathrm{~kg}, m_{B r}=800 \mathrm{~kg}$.

Obliczono szerokości przedziałów zmienności współrzędnych środka ciężkości badanej ładowarki z czerpakiem pustym oraz dla różnego stopnia obciążenia czerpaka urobkiem (Rys. 4). Wzrost masy urobku w czerpaku powoduje przemieszczenie środka ciężkości maszyny w kierunku osi obrotnicy co wpływa niekorzystnie na możliwość wywrócenia się ładowarki do przodu.

W artykule zamieszczono charakterystyki pozwalające na wyznaczenie masy krytycznej urobku dla różnego nachylenia podłużnego i poprzecznego wyrobiska chodnikowego oraz dla dziewięciu charakterystycznych położeń obrotnicy, wysięgnika, wahacza czerpaka i czerpaka. Podane przykładowe przebiegi dotyczą możliwości wywrócenia ładowarki na prawy bok (Rys. 5) i do tyłu (Rys. 6). Podano wartości masy krytycznej urobku znajdującego się w czerpaku badanej ładowarki do pobierki spagu pracującej w wyrobisku chodnikowym o nachyleniu poprzecznym wyrobiska $\beta_{L T}=15^{\circ}$ i $\beta_{L T}=-20^{\circ}$ oraz o nachyleniu podłużnym $\beta_{L G}=16^{\circ}$.

Wnioski z tych badań można wykorzystać przy budowie układu automatyki ostrzegającym przed możliwością wywrócenia się ładowarki podczas pracy w wyrobisku chodnikowym o danym nachyleniu podłużnym i poprzecznym.

Słowa kluczowe: ładowarka do pobierki spagu, środek ciężkości, masa krytyczna, urobek

\section{Introduction}

Tracked mining machines such as roadheaders, drilling and bolting rigs, side-dump loaders and dinting loaders are widely used in the Polish hard coal mine industry. Innovative solutions and constructional changes to such machines have been introduced owing to the research conducted, the aim of which is to enhance their performance and reliability and to lower operating costs (Acargolu \& Ergin, 2006; Dolipski et al., 1998, 2009, 2013; Dolipski \& Cheluszka, 1999; Dolipski \& Sobota, 1998; Ergin \& Acargolu, 2005, 2007; Gospodarczyk et al., 2013; Kotwica, 2011).

Dinting loaders are machines used in roadways (maingates, tailgates, etc.) for mechanisation of works associated with floor ripping and broken rock loading. The performance of such procedures is usually difficult due to the existing equipment and the necessity to maintain regular rail or belt conveyor transport. Dinting loaders of the following companies are used predominantly in 
Polish hard coal mines: Elgór - Zamet, Hazemag, Deilmann Haniel, Ferrit, Hausalit or Sandvik. These are very often multifunctional machines with exchangeable working tools. In such case, a side-dump bucket, drilling and bolting device, hydraulic percussive hammer, service platform or cutter heads can be applied instead of a box-type active or passive bucket.

Due to decreased cross sections of roadways with the upheaved floor, box-type buckets with relatively small dimensions and capacity ranging approx. $0,3 \div 0,4 \mathrm{~m}^{3}$ are employed for dinting. The ripping of floor rocks is carried out with a strengthened lower part of the box-type bucket, which can be additionally furnished with a set of percussive hydraulic hammers. The broken rock is unloaded from the bucket into mining cars or onto a belt conveyor or a scraper conveyor.

Due to the necessity of working in excavations with reduced size, dinting loaders usually have a small width relative to the length. For instance, the width of the loader shown in Fig. 1 is only $1,1 \mathrm{~m}$ which is over 6,7 times smaller than its total length. The boom deflection in the plane parallel to the floor allows to transfer a bucket within the width range of over $4,7 \mathrm{~m}$. When unloading the broken rock, the bucket can be raised to the height of nearly $2,5 \mathrm{~m}$.

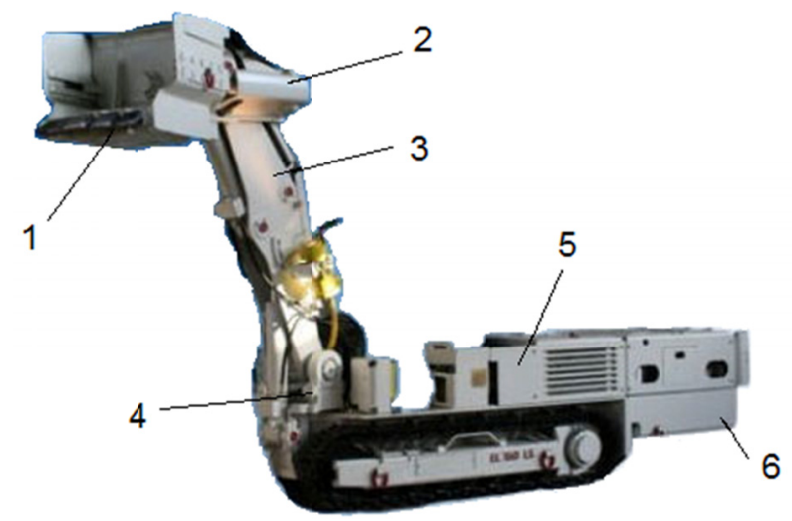

Fig. 1. Dinting loader manufactured by Famur S.A.: 1) bucket, 2) coupler, 3) uniform boom, 4) turntable, 5) tracked body, 6) counterweight

Due to an inconvenient width-to-length ratio of the loader and considerable range of boom and bucket deflection angles as well as operation in excavations with large longitudinal and lateral inclination, the dinting loaders are especially exposed to overturning. A very important factor for dinting loader overturning is the level of load of the bucket, which may change within a very broad range. If the bucket is loaded excessively, a machine - working even within a range of floor longitudinal and lateral inclination angle permitted by manufacturers - may overturn. This is why, taking into consideration the safety of machine operators, it is essential to know the value of broken rock critical mass, for which the dinting loader is in the state of unstable equilibrium.

\section{Mathematical model}

Dinting loaders feature a modular design and are comprised of the following key components (Fig. 1): a body including a machine frame together with all the parts fixed to it permanently, 


\section{4}

counterweight, turntable with the attached boom, coupler and passive bucket or active bucket supplied with a set of hydraulic percussive hammers.

The deflection of the turntable, boom, coupler and bucket, when ripping bottom rocks and unloading the bucket onto haulage equipment, causes the displacement of the centre of gravity of the entire dinting loader. Its position was defined in the global system of spatial coordinates $\mathrm{XYZ}$, as shown in Fig. 2. It was assumed that the axis $\mathrm{Z}$ is coinciding with the turntable's axis of rotation and is perpendicular to the floor plane. The axis X, however, is parallel to the roadway's longitudinal axis, and the direction and sense of the axis $\mathrm{Y}$ results from the right-hand rule.

A gravity force is acting on each subassembly of the studied dinting loader, and its vector initial point is defined in a point reflecting its centre of gravity. The position of such point for each subassembly was specified in a local coordinate system related to this element. The dinting loader subassemblies such as turntable, boom, coupler and bucket are deflected with hydraulic actuators controlled from an operator station. Their deflection is described with angles, i.e. $\alpha_{1}$, $\alpha_{2}, \alpha_{3}$ and $\alpha_{4}$ (Fig. 2). The first two angles define boom position in the plane perpendicular and parallel to the floor plane and the next describe the bucket position in two mutually perpendicular planes. The coordinates of the centre of gravity of a turntable, boom, coupler and bucket in the global coordinate system is determined in formulas with the upper case $G$. It is calculated from the following dependencies, respectively:

$$
\begin{aligned}
& \left\{\begin{array}{l}
x_{T t}^{G}=x_{T t} \cdot \cos \alpha_{2}-y_{T t} \cdot \sin \alpha_{2} \\
y_{T t}^{G}=x_{T t} \cdot \sin \alpha_{2}+y_{T t} \cdot \cos \alpha_{2} \\
z_{T t}^{G}=z_{T t}
\end{array}\right. \\
& \left\{\begin{array}{l}
x_{B m}^{G}=\left(a_{1}+x_{B m} \cdot \cos \alpha_{1}-z_{B m} \cdot \sin \alpha_{1}\right) \cdot \cos \alpha_{2}-y_{B m} \cdot \sin \alpha_{2} \\
y_{B m}^{G}=\left(a_{1}+x_{B m} \cdot \cos \alpha_{1}-z_{B m} \cdot \sin \alpha_{1}\right) \cdot \sin \alpha_{2}+y_{B m} \cdot \cos \alpha_{2} \\
z_{B m}^{G}=c_{1}+x_{B m} \cdot \sin \alpha_{1}+z_{B m} \cdot \cos \alpha_{1}
\end{array}\right. \\
& \left\{\begin{array}{l}
x_{C r}^{G}=\left(a_{1}+l_{B} \cdot \cos \alpha_{1}-a_{2} \cdot \sin \alpha_{1}+x_{C r} \cdot \cos \alpha_{3}-z_{C r} \cdot \sin \alpha_{3}\right) \cdot \cos \alpha_{2}-y_{C r} \cdot \sin \alpha_{2} \\
y_{C r}^{G}=\left(a_{1}+l_{B} \cdot \cos \alpha_{1}-a_{2} \cdot \sin \alpha_{1}+x_{C r} \cdot \cos \alpha_{3}-z_{C r} \cdot \sin \alpha_{3}\right) \cdot \sin \alpha_{2}+y_{C r} \cdot \cos \alpha_{2} \\
z_{C r}^{G}=c_{1}+l_{B} \cdot \sin \alpha_{1}+a_{2} \cdot \cos \alpha_{1}+x_{C r} \cdot \sin \alpha_{3}+z_{C r} \cdot \cos \alpha_{3}
\end{array}\right. \\
& x_{B t}^{G}=\left[a_{1}+l_{B} \cdot \cos \alpha_{1}-a_{2} \cdot \sin \alpha_{1}-\left(a_{4}+z_{B t}\right) \cdot \sin \alpha_{3}+a_{3} \cdot \cos \alpha_{3}\right] \cdot \cos \alpha_{2}+ \\
& +\left(x_{B t} \cdot \cos \alpha_{4}-y_{B t} \cdot \sin \alpha_{4}\right) \cdot \cos \alpha_{3} \cdot \cos \alpha_{2}-\left(y_{B t} \cdot \cos \alpha_{4}+x_{B t} \cdot \sin \alpha_{4}\right) \cdot \sin \alpha_{2} \\
& y_{B t}^{G}=\left[a_{1}+l_{B} \cdot \cos \alpha_{1}-a_{2} \cdot \sin \alpha_{1}-\left(a_{4}+z_{B t}\right) \cdot \sin \alpha_{3}+a_{3} \cdot \cos \alpha_{3}\right] \cdot \sin \alpha_{2}+ \\
& +\left(x_{B t} \cdot \cos \alpha_{4}-y_{B t} \cdot \sin \alpha_{4}\right) \cdot \cos \alpha_{3} \cdot \sin \alpha_{2}+\left(y_{B t} \cdot \cos \alpha_{4}+x_{B t} \cdot \sin \alpha_{4}\right) \cdot \cos \alpha_{2} \\
& z_{B t}^{G}=c_{1}+l_{B} \cdot \sin \alpha_{1}+a_{2} \cdot \cos \alpha_{1}+\left(a_{4}+z_{B t}\right) \cdot \cos \alpha_{3}+ \\
& +\left(a_{3}+x_{B t} \cdot \cos \alpha_{4}-y_{B t} \cdot \sin \alpha_{4}\right) \cdot \sin \alpha_{3}
\end{aligned}
$$

where:

$x, y, z$ - spatial coordinates of centres of gravity of particular elements determined in local coordinate systems related to such elements, 


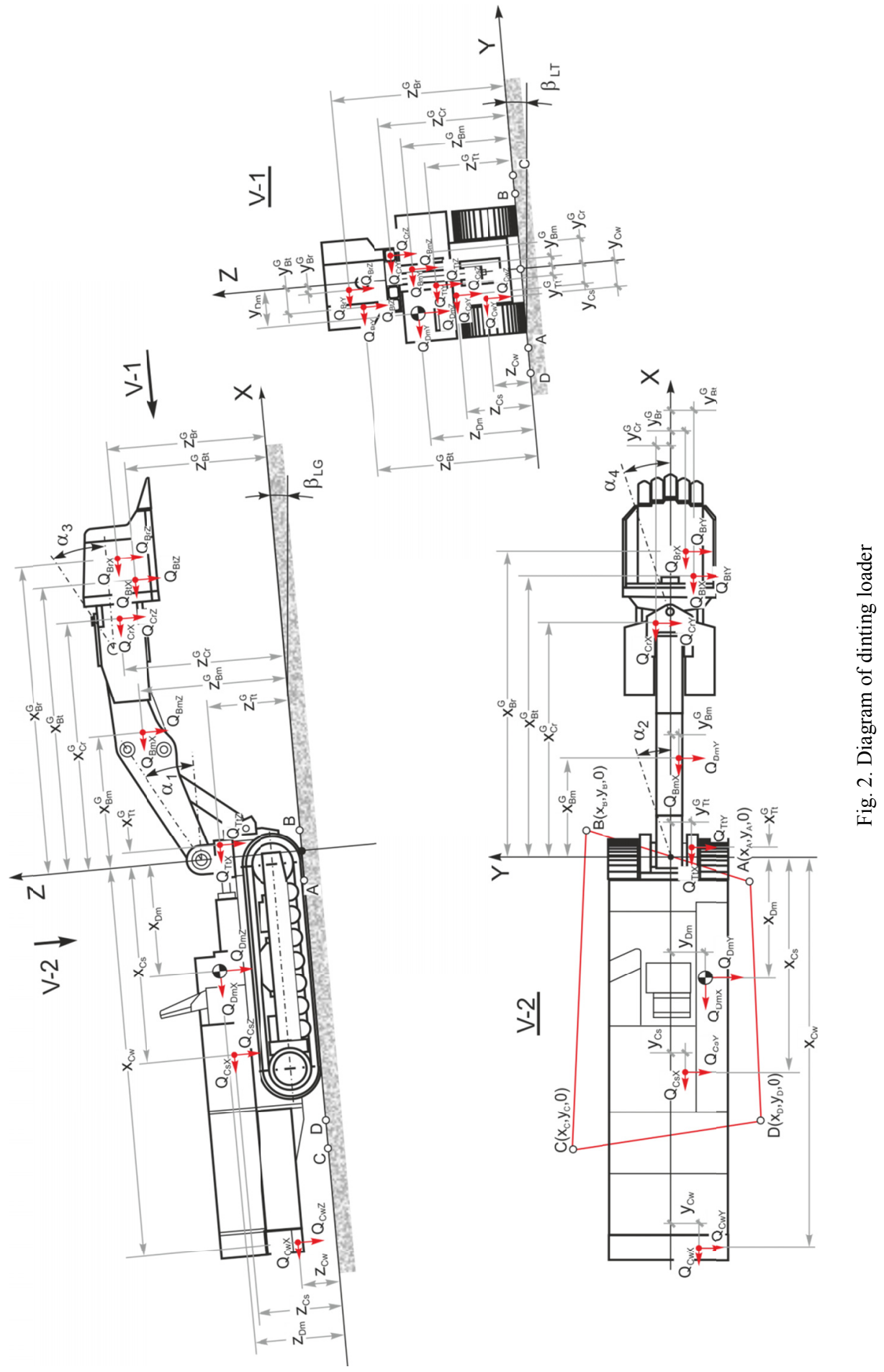


$x^{G}, y^{G}, z^{G}$ - spatial coordinates of centres of gravity of particular elements determined in global coordinate system,

$a, c, l-$ geometrical dimensions characteristic for the considered elements of the dinting loader.

Lower cases in the formulas (1), (2), (3) and (4) denote subsequent elements of the loader construction: $\mathrm{Tt}$ - turntable, $\mathrm{Bm}$ - boom, $\mathrm{Cr}$ - coupler, $\mathrm{Bt}$ - bucket.

The coordinates of centres of gravity of the dinting loader body and counterweight are denominated, respectively, as $x_{C s}, y_{C s}, z_{C s}$ and $x_{C w}, y_{C w}, z_{C w}$. Their values are measured directly in the adopted global coordinate system XYZ.

Broken rock, after loading into a bucket, is transferred with the bucket to the unloading point. For this reason, coordinates of the centre of gravity of broken rock in the bucket are described in a local coordinate system of the bucket. They are determined in the global coordinate system of the loader, however, using the dependency (4), by inserting - instead of the lower case "Bt" - "Br" case denoting broken rock.

The coordinates of the centre of gravity of the studied dinting loader were determined as a ratio of the sum of the product of gravity forces of particular machine parts and coordinates of centres of gravity of such parts, measured in relation to a given axis of the adopted global coordinate system for the total loader weight (Dolipski \& Sobota, 1998):

$$
\left\{\begin{array}{r}
x_{D m}=Q_{D m}^{-1} \cdot\left(\begin{array}{l}
Q_{C S} \cdot x_{C s}+Q_{C w} \cdot x_{C w}+Q_{T t} \cdot x_{T t}^{G}+Q_{B m} \cdot x_{B m}^{G}+ \\
+Q_{C r} \cdot x_{C r}^{G}+Q_{B t} \cdot x_{B t}^{G}+Q_{B r} \cdot x_{B r}^{G}
\end{array}\right) \\
y_{D m}=Q_{D m}^{-1} \cdot\left(\begin{array}{l}
Q_{C s} \cdot y_{C s}+Q_{C w} \cdot y_{C w}+Q_{T t} \cdot y_{T t}^{G}+Q_{B m} \cdot y_{B m}^{G}+ \\
+Q_{C r} \cdot y_{C r}^{G}+Q_{B t} \cdot y_{B t}^{G}+Q_{B r} \cdot y_{B r}^{G}
\end{array}\right) \\
z_{D m}=Q_{D m}^{-1} \cdot\left(\begin{array}{l}
Q_{C s} \cdot z_{C s}+Q_{C w} \cdot z_{C w}+Q_{T t} \cdot z_{T t}^{G}+Q_{B m} \cdot z_{B m}^{G}+ \\
+Q_{C r} \cdot z_{C r}^{G}+Q_{B t} \cdot z_{B t}^{G}+Q_{B r} \cdot z_{B r}^{G}
\end{array}\right)
\end{array}\right.
$$

whereas

$$
Q_{D m}=Q_{C s}+Q_{C w}+Q_{T t}+Q_{B m}+Q_{C r}+Q_{B t}+Q_{B r}
$$

where: $Q$ - gravity forces, lower case means: $D m$ - loader, $C s$ - body, $C w$ - counterweight, $T t$ - turntable, $\mathrm{Bm}$ - boom, $\mathrm{Cr}$ - coupler, $\mathrm{Bt}$ - bucket, $\mathrm{Br}$ - broken rock in a bucket.

The loader's centre of gravity is a point in space to which a resultant vector of forces of gravity, coming from the particular loader components and from the broken rock in the bucket, is attached. In the case where the vector penetrates the floor plane inside the contour of support, marked in Fig. 2 by means of a quadrangle with its vertexes ABCD, the loader does not overturn in such case. On the other hand, when the penetration point is situated outside the contour of support $\mathrm{ABCD}$, the loader will then overturn due to the acting force of gravity. However, when the considered penetration point is situated on the contour of support (overturn line), the loader will then be in the state of unstable equilibrium.

The critical mass of broken rock in the bucket can be established from a condition resulting from the state of unstable equilibrium for the known resultant value of the force of gravity 
and coordinates of the centre of gravity of the dinting loader in the adopted coordinate system for different positions of the turntable, boom, coupler and bucket. The muck in the bucket has critical mass when - for the assumed values of angles of lateral inclination $\beta_{L T}$ and longitudinal inclination $\beta_{L G}$ of a roadway - the penetration point of the resultant vector of the force of gravity of the loader and floor plane is situated on one of the adopted overturn lines.

The possibility of a dinting loader being overturned in underground excavations is closely connected with the safety of machine operators. The machine may overturn forward or backward and to the right or left side (Borkowski et al., 1996). Such directions are determined in relation to the operator located on a machine with front to the travelling direction.

The safety of tracked mining machinery is discussed by, among others, the following standards: PN-ISO 8313:1996, PN-ISO 10567:1996, PN-G-50033:1996, PN-EN 791:1998, PN-EN 12111:2005. The documents distinguish machines equipped with additional support legs increasing the area inside the support contour and machines without support legs. For machines without additional support legs, a straight line - connecting the centres of both idlers and both sprockets - should be considered to be a forward and backward overturn line. On the other hand, when a track's running on angle and running off angle $\beta$ is larger than two degrees, then the considered overturn lines are running through the centres of the terminal road wheels. When considering the possibility of overturning a tracked mining machine to the left or right side, a straight line routed through the contact points of road wheels with the interworking track links is adopted as the overturn line. An overturn line position is therefore dictated by the construction of such elements.

A diagram in Figure 2 shows overturn lines marked with points A, B, C and D. The section $\mathrm{AB}$ is a forward overturn line, $\mathrm{CD}$ - backward overturn line and $\mathrm{AD}$ and $\mathrm{BC}$, respectively, overturn lines to the right and left side. The coordinates of the considered points in the created mathematical model can be defined in freely, which allows to model overturn lines for machines with and without additional support legs.

\section{Computer investigations}

While performing floor ripping, the bucket load results from the degree of bucket filling with broken rock and from the rock density. For example, bulk density of hard coal varies within the range of $1,2 \mathrm{~g} / \mathrm{cm}^{3}$ to $1,5 \mathrm{~g} / \mathrm{cm}^{3}$, for silty shale from $1,77 \mathrm{~g} / \mathrm{cm}^{3}$ to $3,2 \mathrm{~g} / \mathrm{cm}^{3}$ and for sandstone from $1,61 \mathrm{~g} / \mathrm{cm}^{3}$ to $2,76 \mathrm{~g} / \mathrm{cm}^{3}$ (Telford et al., 1990). It was therefore assumed that for a box-type bucket with the capacity of $0,3 \mathrm{~m}^{3}$, the nominal mass of broken rock inside is equal $m_{B r N}=960$ $\mathrm{kg}$, and for a bucket with the capacity of $0,4 \mathrm{~m}^{3}-m_{B r N}=1280 \mathrm{~kg}$. The dinting loader may be applied, sometimes, for uses contrary to its designed use, for instance for raising steel parts with the weight greatly exceeding the nominal values of bucket load. An increased load on the bucket with an operational load was therefore simulated during computer studies.

Investigations aimed at determining the critical mass of broken rock in the bucket were carried out with an established mathematical model and computer software launched in Matlab - the environment for scientific and engineering computations. The research object was a dinting loader manufactured by Elgór+Zamet Sp. z o.o. based in Piekary Śląskie.

The value of the critical mass of the broken rock in the bucket for a given angle of longitudinal and lateral inclination of a roadway and the adopted overturn lines depend on the instantaneous values of the spatial coordinates of the machine's centre of gravity. 
The coordinates of the centre of gravity of the loader $\left(x_{D m}, y_{D m}, z_{D m}\right)$ in the adopted global coordinate system XYZ for different positions of the turntable, boom, coupler and bucket within the entire variability range of values of angles $\alpha_{1}, \alpha_{2}, \alpha_{3}$ and $\alpha_{4}$ were determined in the computer simulations.

Figure 3a shows an example of three mathematically established clouds of points located next to each other. They represent the position of centres of gravity of the dinting loader for various possible settings of the turntable, boom, coupler and bucket in the entire possible variability range of angles $\alpha_{1}, \alpha_{2}, \alpha_{3}$ and $\alpha_{4}$. Each cloud of points corresponds to a different broken rock load of the bucket. The positions of a centre of gravity for an empty bucket and such loaded with broken rock weighing $400 \mathrm{~kg}$ and $800 \mathrm{~kg}$ were presented. Figures $3 \mathrm{~b}, 3 \mathrm{c}$ and $3 \mathrm{~d}$ show views of the considered clouds on the planes, respectively, YZ, XZ and XY.

a)

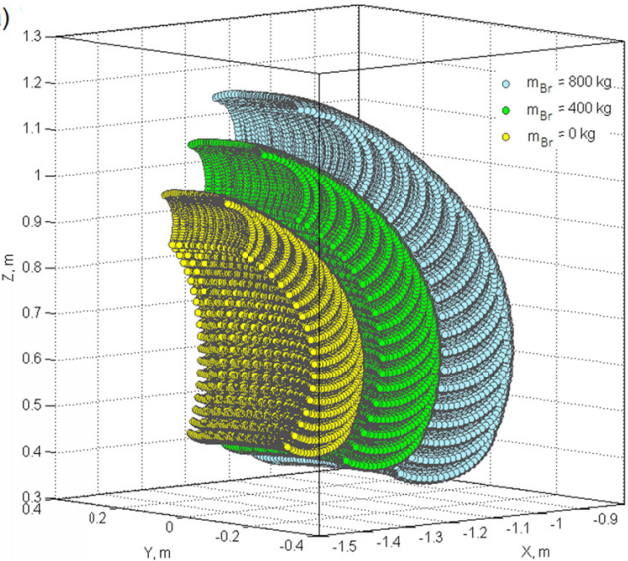

c)

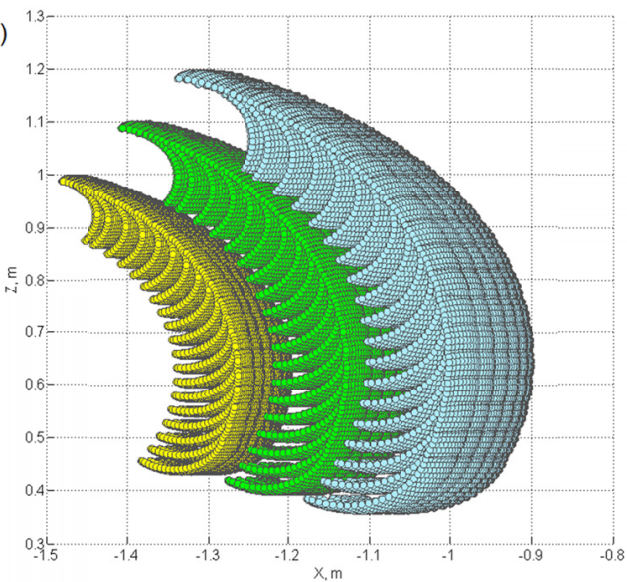

b)

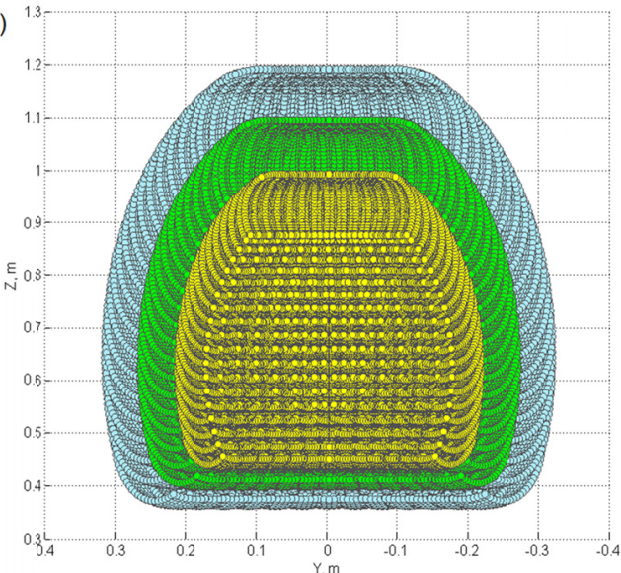

d)

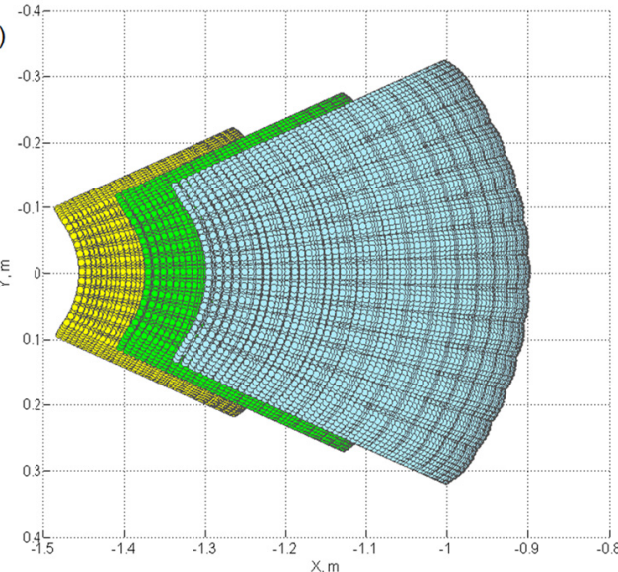

Rys. 3. Clouds of points showing possible position of centre of gravity of the dinting loader for the whole deflections range of the boom, coupler and bucket in the adopted global coordinate system for $m_{B r}=0 \mathrm{~kg}, m_{B r}=400 \mathrm{~kg}, m_{B r}=800 \mathrm{~kg}$ : a) view XYZ, b) view of plane $\mathrm{YZ}$,

c) view of plane $X Z, d$ ) view of plane $X Y$ 
Variability ranges of spatial coordinates determining the position of the dinting loader's centre of gravity are changing considerably and account for, for an empty bucket (Fig. 3):

- for coordinate $x$, from $-1,482 \mathrm{~m}$ to $-1,200 \mathrm{~m}$,

- for coordinate $y$, from $-0,217 \mathrm{~m}$ to $0,213 \mathrm{~m}$,

- for coordinate $z$, from $0,436 \mathrm{~m}$ to $0,991 \mathrm{~m}$.

The width of the variability range of the considered coordinates equals, therefore, $0,282 \mathrm{~m}$, $0,430 \mathrm{~m}$ and $0,555 \mathrm{~m}$, respectively, in the direction $\mathrm{X}, \mathrm{Y}$ and $\mathrm{Z}$. The values are important especially due to the fact that the machine width measured in the direction of axis $Y$ is only $1,1 \mathrm{~m}$ and its height (in the direction $\mathrm{Z}$ ) equals $1,12 \mathrm{~m}$.

Loading a dinting machine bucket with broken rock weighing $m_{B r}=400 \mathrm{~kg}$ and then $m_{B r}=800 \mathrm{~kg}$ had a major effect on the position of the loader's centre of gravity in the adopted global coordinate system (Fig. 3). As the mass of broken rock in the bucket is growing, the cloud of points reflecting the machine's coordinates of the centre of gravity along the axis X, has moved in the direction of the turntable axis of rotation. This has a negative effect on the machine's potential forward overturn. The width of variability ranges of coordinates of the centre of gravity towards each axis has also increased. For example, for $m_{B r}=800 \mathrm{~kg}$, the position of the centre of gravity has changed in the direction of axis $\mathrm{X}$ from $-1,338 \mathrm{~m}$ to $-0,904 \mathrm{~m}$, in the direction of axis $Y$ from $-0,318 \mathrm{~m}$ to $0,315 \mathrm{~m}$ and in the direction of axis $\mathrm{Z}$ from $0,363 \mathrm{~m}$ to $1,189 \mathrm{~m}$. When making a reference to a case with an empty bucket, the width of variability ranges of coordinates $x, y$ and $z$ has grown by, respectively, $54 \%, 47 \%$ and $49 \%$.

The coefficient $k_{m}$, with its value equal to the ratio of the broken rock mass loading the dinting loader bucket to the machine's total weight, was defined for the purpose of the conducted investigations. Figure 4 presents the effect of this coefficient value on the extreme values of coordinates $x, y$ and $z$ of the loader's centre of gravity according to deflection of the turntable, boom, coupler and bucket within the entire achievable variability range of angles $\alpha_{1}, \alpha_{2}, \alpha_{3}$ and $\alpha_{4}$. Within the entire investigated range of bucket load, the growth of the coefficient $k_{m}$ is increasing the width of variability ranges of the coordinates $x, y$ and $z$ of the loader's centre of gravity.

A temporary position of the turntable, boom, coupler and bucket has influence not only on the position of the loader's centre of gravity but also on the value of critical mass of broken rock in a bucket for given values of deflection angles of the longitudinal and lateral inclination of a roadway and for the adopted overturn lines. For the purpose of determination the critical mass of broken rock in the bucket, nine characteristic positions of the turntable, boom, coupler and bucket were specified, which are determined by the values of angles $\alpha_{1}, \alpha_{2}, \alpha_{3}$ and $\alpha_{4}$ (Tab. 1). Such positions include, among others, the extreme boom deflections in the plane parallel to the floor and perpendicular to the floor and an extreme positions of the coupler and the bucket.

Overturn lines to the right side, left side, forward and backward are determined by coordinates of points A, B, C and D (Fig. 2). The studied dinting loader is not furnished with additional support legs and the value of angle $\beta$ for this machine is larger than two degrees. The following coordinates of the points $\mathrm{A}, \mathrm{B}, \mathrm{C}$ and $\mathrm{D}$ were therefore assumed for computer simulations: $x_{A}=-0,375 \mathrm{~m}, y_{A}=-0,465 \mathrm{~m}, x_{B}=-0,375 \mathrm{~m}, y_{B}=0,465 \mathrm{~m}, x_{C}=-1,665 \mathrm{~m}, y_{C}=0,465 \mathrm{~m}$, $x_{D}=-1,665 \mathrm{~m}, y_{D}=-0,465 \mathrm{~m}$.

The critical mass of broken rock in a dinting loader bucket may be determined based on characteristics presented in figures 5 and 6 . They relate to the machine's overturn lines for the right side $(\mathrm{AD})$ and backward $(\mathrm{CD})$. The curves presented were determined for nine predefined 


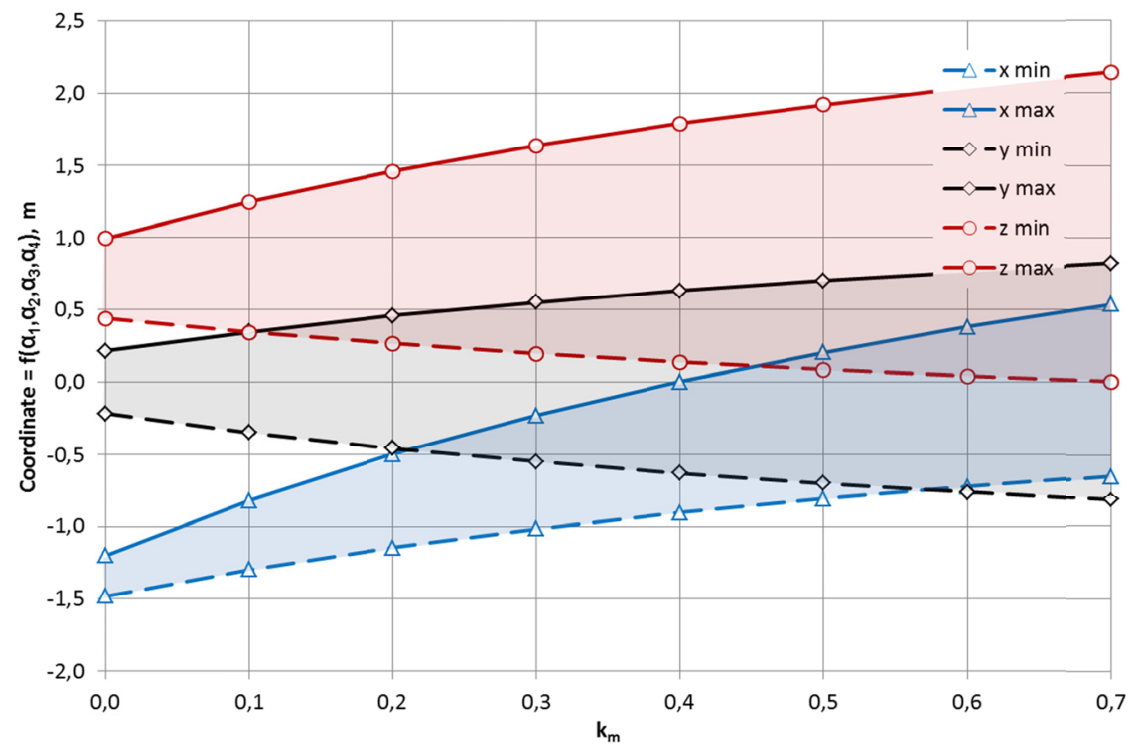

Fig. 4. Variability ranges of the coordinates $x, y$ and $z$ of the dinting loader's centre of gravity depending on the value of coefficient $k_{m}$

Characteristic positions of a turntable, boom, coupler and bucket

\begin{tabular}{|c|c|c|c|c|}
\hline Name & $\boldsymbol{\alpha}_{\mathbf{1}}[\mathbf{d e g}]$ & $\boldsymbol{\alpha}_{\mathbf{2}}[\mathbf{d e g}]$ & $\boldsymbol{\alpha}_{\mathbf{3}}[\mathbf{d e g}]$ & $\boldsymbol{\alpha}_{\mathbf{4}}[\mathbf{d e g}]$ \\
\hline $\mathrm{c} 1$ & -10 & -29 & -88 & -29 \\
\hline $\mathrm{c} 2$ & 0 & -29 & 0 & -29 \\
\hline $\mathrm{c} 3$ & 78 & -29 & 26 & -29 \\
\hline $\mathrm{c} 4$ & -10 & 0 & -88 & 0 \\
\hline $\mathrm{c5}$ & 0 & 0 & 0 & 0 \\
\hline $\mathrm{c} 6$ & 78 & 0 & 26 & 0 \\
\hline $\mathrm{c} 7$ & -10 & 29 & -88 & 29 \\
\hline $\mathrm{c} 8$ & 0 & 29 & 0 & 29 \\
\hline $\mathrm{c} 9$ & 78 & 29 & 26 & 29 \\
\hline
\end{tabular}

characteristic settings of the turntable, boom, coupler and bucket marked, respectively, with symbols $c 1, c 2, \ldots, c 9$.

For instance, when a dinting loader is working in a gate road with the lateral inclination of $\beta_{L T}=15^{\circ}$ and the turntable, boom, coupler and bucket are in the position $c 3$, then the critical mass of broken rock is $524,5 \mathrm{~kg}$ (Fig. 5). This means that the load on the bucket with higher value will overturn the machine to the right side. In turn, when the lateral inclination of the excavation equals $-20^{\circ}$ and the deflected elements are set in the position $c 2$, the machine's overturn to the right side would occur after loading the bucket with broken rock with mass higher than $4720,5 \mathrm{~kg}$. 


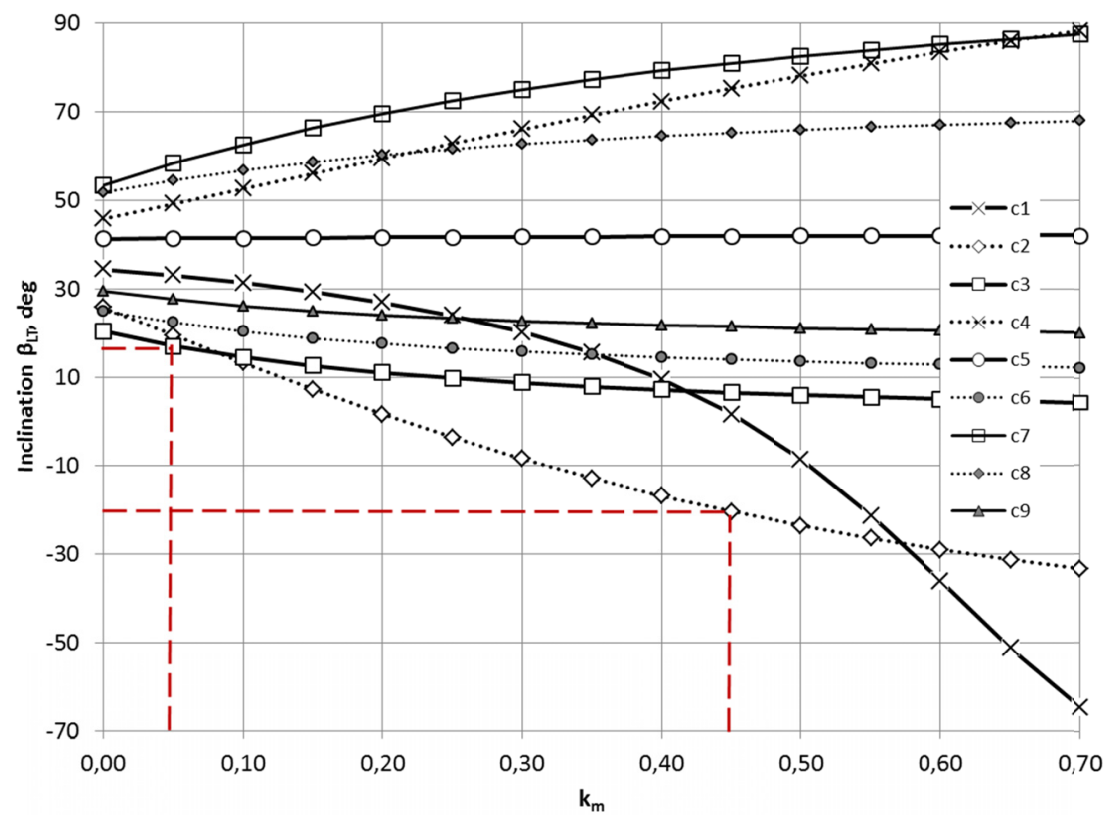

Fig. 5. The effect of coefficient $k_{m}$ value on the limit value of lateral inclination angle of a gate road for overturn line $\mathrm{AD}$

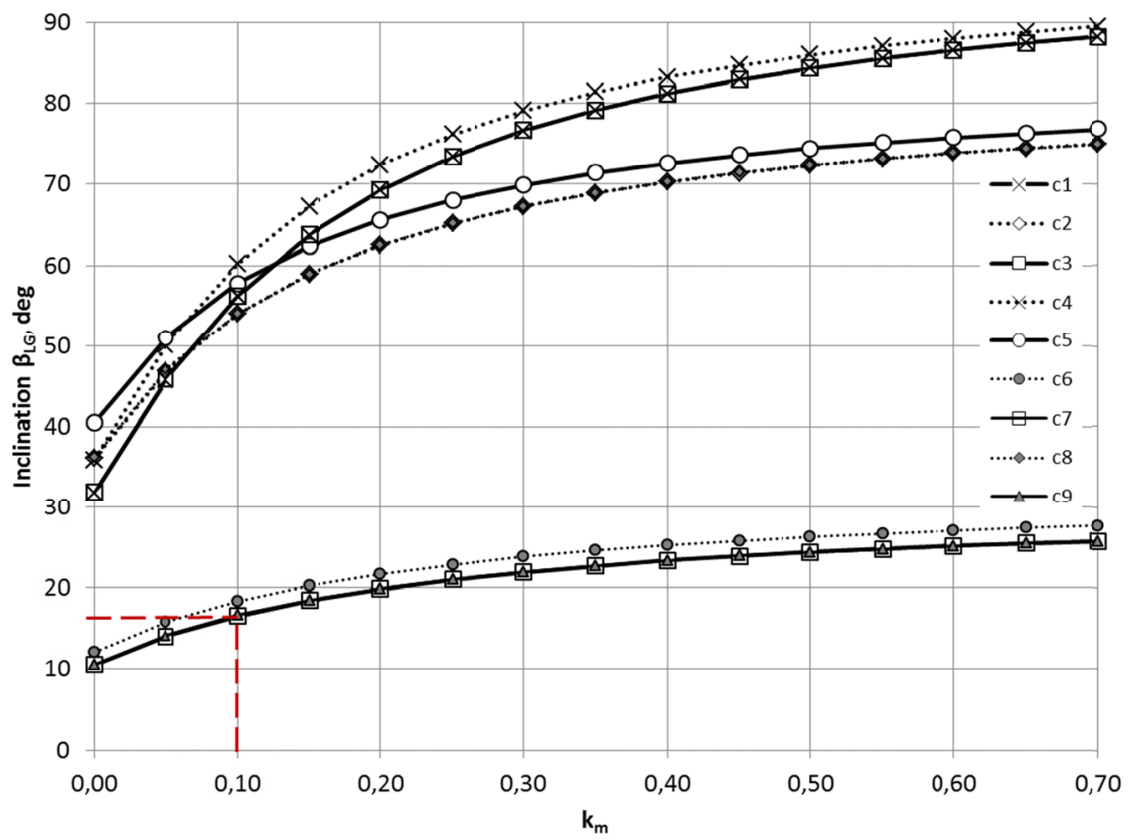

Fig. 6. The effect of coefficient $k_{m}$ value on the limit value of longitudinal inclination angle of a gate road for overturn line $\mathrm{CD}$ 
For a machine working in a gate road with the longitudinal inclination of $\beta_{L G}=16^{\circ}$ and for the characteristic position of the turntable, boom, coupler and bucket of $c 3$ and $c 9$, the critical mass of broken rock in the bucket is $1,049 \mathrm{~kg}$. The broken rock load on the bucket with higher mass will overturn the machine backwards in such two cases.

\section{Summary}

An adequate mathematical model of a dinting loader was elaborated in order to determine the critical mass of broken rock in a bucket for the given longitudinal and lateral inclination of a roadway considering the possibility of deflection of a turntable, boom, coupler and bucket. This model also allows to:

- analyse the variability of spatial coordinates of a centre of gravity for a dinting loader depending on temporary deflection of a turntable, boom, coupler and bucket and on the mass of broken rock in the bucket,

- determine limits of longitudinal and lateral inclination angles of a roadway for which the loader will be in the state of unstable equilibrium.

A machine's behaviour in underground excavations can be judged by knowing variations in the position of the centre of gravity of a dinting loader due to the deflection of the turntable, boom, coupler and bucket (which may be loaded with broken rock). The width of variability ranges of coordinates of the centre of gravity of the investigated loader with an empty bucket was $0,282 \mathrm{~m}$, $0,430 \mathrm{~m}$ and $0,555 \mathrm{~m}$ respectively, in the direction of axis $\mathrm{X}, \mathrm{Y}$ and $\mathrm{Z}$. The broken rock load of the bucket with the mass of $800 \mathrm{~kg}$ has increased the width of such ranges by, respectively, $54 \%$, $47 \%$ and $49 \%$. An increase in broken rock weight in a bucket has also displaced the gravity centre of the machine in the direction of the turntable axis of rotation, which has a negative effect on the potential forward overturn of the machine.

The examples of values of the established critical mass of the broken rock in the studied dinting loader's bucket working in a gate road equal:

- $m_{B r C}=524,5 \mathrm{~kg}$, which is $55 \%$ of the nominal weight of broken rock in a bucket. The lateral inclination of the excavation was $\beta_{L T}=15^{\circ}$. The boom and bucket were raised maximally upwards and the turntable and coupler were in an extreme right position. The broken rock load on the bucket with higher mass will overturn the machine to the right side.

- $m_{B r C}=1049 \mathrm{~kg}$, for the longitudinal inclination of the excavation $\beta_{L G}=16^{\circ}$. The critical mass value in this case is higher by $9 \%$ than the nominal mass of broken rock in the bucket. The boom and the bucket were in an extreme top position. The turntable and coupler were deflected maximally to the right or left, though. The broken rock load on the bucket with higher mass will overturn the machine backwards.

The conclusions from such investigations can be used for construction of automatics systems warning against potential loader overturn during work in an underground excavation when the mass of broken rock in a bucket is similar to the critical mass, for the given longitudinal and lateral inclination of the excavation. 


\section{References}

Acaroglu O., Ergin H., 2006. A new method to evaluate roadheader operational stability. Tunneling and Underground Space Technology 21, 2, 172-179.

Borkowski W., Konopka S., Prochowski L., 1996. Dynamika maszyn roboczych. Wydawnictwo Naukowo-Techniczne, Warszawa.

Dolipski M., Cheluszka P., 1999. Dynamic model of a roadheader's cutting system which incorporates transverse cutter heads. Arch. Min. Sci. 44, 1, 113-146.

Dolipski M., Cheluszka P., Remiorz E., Sobota, P., 2009. Problemy stateczności maszyn górniczych na podwoziu gąsienicowym. Work Safety and Environmental Protection in Mining 184, 12, 7-12.

Dolipski M., Cheluszka P., Sobota P., 2013. The Relevance of the Rotational Speed of Roadheader Cutting Heads According to the Energy Consumption of the Cutting Process. Arch. Min. Sci. 58, 1, 3-19.

Dolipski M., Sobota P., 1998. Badania zmiany położenia środka ciężkości kombajnu chodnikowego. Maszyny Górnicze 16, 1, 23-29.

Dolipski M., Sobota P., Cheluszka P., 1998. Stateczność kombajnu chodnikowego. Przegląd Górniczy 54, 4, 10-18.

Ergin H., Acaroglu O., 2005. The effect of cutting head shapes on roadheader stability. Mining Technology 114, 3, $140-146$.

Ergin H., Acaroglu O., 2007. The effect of machine design parameters on the stability of a roadheader. Tunnelling and Underground Space Technology 22, 1, 80-89.

Gospodarczyk P., Kotwica K., Stopka G., 2013. A new generation mining head with disc tool of complex trajectory. Arch. Min. Sci. 58, 4, 985-1006.

Kotwica K., 2011. The influence of water assistance on the character and degree of wear of cutting tools applied in roadheaders. Arch. Min. Sci. 56, 3, 353-374.

Telford W.M., Geldart L.P., Sheriff R.E., 1990. Applied Geophysics. Second Edition. Cambridge Univ. Press, Cambridge. 